\title{
CHEMICAL COMPOSITION AND SOME CHARACTERISTCS OF POMEGRANATE JUICE EXTACTED BY SQUEEZING AND CENTRIFUGATION METHODS
}

\author{
Abdullah M. Thannoun \\ Maeda M. Tayib
}

Food Science Department, Collage of Agriculture and Forestry, Mosul University, Iraq

\begin{abstract}
Pomegranate (Punica granatum L.) juices of three local varieties, namely, sour, sour sweet and sweet according to their taste were extracted using squeezing and centrifugation methods. Juices produced and local commercial pomegranate were investigated and analyzed for revenue percent and their proximate composition, ascorbic acid, sugars concentration, $\mathrm{pH}$ value and titrable acidity. Results showed that more juice was obtained by using centrifugation compared with squeezing method for all three kinds of pomegranate. Results also show that the range of moisture, Total Soluble Solid (TSS), protein, fat extract, crude fibers, ash, carbohydrate and energy were $81.3-86.2,11.2-17.2,0.6-0.8,0.55-0.85,0.1-0.6,0.40-0.56,12.02-15.93 \%$ and $55.88-74.57 \mathrm{kcal} / 100 \mathrm{ml}$, respectively. While, the range of total, reducing and non reducing sugars, glucose, fructose, ascorbic acid, $\mathrm{pH}$ value and titrable acidity were 11.81-16.57, 11.4-16.17, 0.38-0.41, 5.2-8.2, 5.8-7.8 g/100ml, 5.95-7.1 mg/100ml, 2.593.71 and $0.51-3.52 \%$, respectively. Generally, it was concluded that there were significant $(\mathrm{P}<0.05)$ differences in some characteristic of pomegranate juice between the two methods of extraction for all three pomegranate varieties.
\end{abstract}

Keywords: Ascorbic acid, chemical composition, extraction method, pomegranate juice, reducing sugars

Received: 22/4/2012 Accepted 18/6/2012.

\section{INTRODUCTION}

The pomegranate, Punica granatum L., is an ancient, mystical, unique fruit borne on a small, long-living tree cultivated throughout the Mediterranean region, Middle East, Southeast Asia, and Southwestern of United States (Jurenka, 2008). It has been used extensively in various cultures around the world as a traditional medicine for centuries (Aviram et al., 2000). Pomegranate has become popular as a result of therapeutic and health beneficial effects for human related to its antioxidative, antidiabetic, hypolipidemic, antibacterial, antiinflammatory, antiviral, and anticarcinogenic activities (Lansky and Newman, 2007; Jurenka, 2008, and ViudaMartos et al., 2010).

Nowadays; researchers have interest in the juice and the fruit as whole to study their composition and their effects on the different aspects of the human health and animals. Edible parts of pomegranate fruit namely; arils comprise $80 \%$ juice and $20 \%$

Research is a part of Thesis of second author 
seeds (Aviram et al. 2000) and the fresh juice contains more than 85\% water, 10-15\% total sugars, $1.5 \%$ pectin, vitamin C and most of vitamin B complex (El-Nemr et al., 1990, Aviram et al., 2000 and Anonymous, 2011). Further, as a fruit, pomegranate contains a wide range of polyphenolic compounds including ellagitannins, ellagic acid, flavonoids, anthocyanidins, tannins, as well as rich in many vitamins (Gil et al., 2000; Seeram et al. 2006 and Jurenka, 2008). Some of these polyphenolic compounds, which are high in the fruit peels, are extracted into the juice (Seeram et al., 2006). However, the composition of pomegranate and its components depends on several factors such as cultivar type, environmental and postharvest factors, storage and processing techniques (Gil et al., 2000 and Melgarejo et al., 2000). Studies showed that industrial processing had an effect on pomegranate extracts in which commercial juices contained more tannin punicalagin compared with laboratory arils experimental juice refer to present of hydralyzable tannins from fruit rind (Clifford and Scalbert, 2000 and Gil et al., 2000). The effect of using different methods of extraction of the pomegranate juice on its quality and stability was evaluated by Miguel et al. (2004) and such methods did not significantly affect the evaluated characteristics of juice quality. The aim of our research as a first attempt was to determine the chemical composition and some characteristics of certain local pomegranate juices using traditional extraction methods.

\section{MATERIALS AND METHODS}

Pomegranate fruits source: Pomegranate fruits (Punica granatum L.) were obtained from Armishy village in Zakho/ Northern of Iraq and this species of pomegranate is characterized by small arils and has three kinds classified according to its taste as follows: Sour, Sour-Sweet and Sweet pomegranate. Local pomegranate juice was obtained from local markets.

Pomegranate Juice Preparation: The damaged and injured fruits were discarded from the three batches and the remaining uniform size fruits were washed carefully by tap water then each batch was divided into two parts to extract the juice by two different methods according to method mentioned by Miguel et al. (2004).

Squeezing Method: In this method, the fruits were divided into two halves and the juice was extracted by special fruits compressing (squeezer) machine and the juice was sieved through $0.08 \mathrm{~mm}$ mesh and the juice was immediately packed in plastic bottles and stored in the freezer $\left(-18^{\circ} \mathrm{C}\right)$ for analysis in the next steps.

Centrifugation method: In this method the fruits were manually peeled and the seeds or arils were separated, washed and the juice was extracted by electric home extractor or blender. The seeds were discarded and the juice was sieved through $0.08 \mathrm{~mm}$ mesh and the juice was immediately packed in plastic bottles and stored in the freezer (-18 ${ }^{\circ} \mathrm{C}$ ) for analysis in the next steps. At the end of these processes seven samples of pomegranate juices were obtained as a result of two methods of extraction of three kinds of pomegranate fruits in addition to the commercial local pomegranate juice.

\section{Chemical Analysis was performed as followed:}

Moisture was determined according to method mentioned in Anonymous (2000) using electric vacuum oven made by Memmert Company at $105^{\circ} \mathrm{C}$ and $100 \mathrm{mmHg}$ pressure. 
Protein was determined by Macrokjeldahl method using technique mentioned in Anonymous (2000). Fat was determined by Soxhlet apparatus using method mentioned in Anonymous (2000). Fibers were determined using method mentioned in Anonymous (2000). Ash was determined according to method mentioned in Anonymous (2000) using Muffle Furnace made by Thermolyn Company at $550^{\circ} \mathrm{C}$ overnight or to complete ashing by obtaining white ash. However, carbohydrates were calculated by difference. total soluble solids materials (TSS) were determined by Hand Refractometer measuring scale between 0 and 50\%. The $\mathrm{pH}$ values were measured using $\mathrm{pH}$ meter MODL NO 6171 China made. Titrable acidity was determined as percentage of citric acid by titrating $10 \mathrm{~mL}$ of the filtrated juice with a solution of $0.1 \mathrm{~N} \mathrm{NaOH}$ (Ling, 1963).

Total sugars were determined by using Lane and Eynon method which was mentioned by Ranganna (1977). The reducing sugars were determined by using 3,5 Dinitrosalicylic acid (DNS) mentioned in Anonymous (2000). Whereas non reducing sugars were calculated by the following equation

Total sugars $=$ Reducing sugars + non reducing sugars .

Glucose and fructose were determined according to the method mentioned in Anonymous (2000).

Ascorbic acid (vitamin C) was determined according to method mentioned in Anonymous (2000) using 2, 6 dichloro phenol Indophenol dye.

Statistical Analysis: Data were analyzed by one way analysis of Variance and Standard deviations were calculated by using Duncan's Multiple Range Test (Steel and Torrie, 1980).

\section{RESULTS AND DISCUSSION}

Table (1) shows the weights of fresh pomegranate, arils, juice and percent revenue of centrifugation and squeezing methods used to extract the pomegranate juices. Results show that the highest weight of arils $(761 \mathrm{~g})$ was obtained from sour-sweet pomegranate compared with 673 and $671 \mathrm{~g}$ from sour and sweet pomegranate, respectively. The juice weights of all kinds of fruits for both methods ranged between 375 to $555 \mathrm{~g}$. Weight of juice obtained from sour pomegranate was 375 and $525 \mathrm{~g}$ using squeezing and centrifugation methods of extraction, respectively, and 525 and $555 \mathrm{~g}$ of juice from sour sweet pomegranate using the above two methods, respectively and 375 and $550 \mathrm{~g}$ of juice from sweet pomegranate using also the above two methods, respectively. These results show that more juices were obtained from fresh fruits by using centrifugation compared with squeezing method for all three kinds of pomegranate. Consequently, the revenue of juice was high $(51.8,54$ and 54.8\%) from respective sour, sour-sweet and sweet pomegranate fruits by using centrifugation method of extraction compared with lower percent (37, 52 and 37\%) from respective sour, sour-sweet and sweet pomegranate fruits by using squeezing method of extraction. Same methods were applied in extraction of pomegranate juice by Miguel et al. (2004), who deducted some differences in some components but they didn't show the revenue percent of these methods. Comparable results of some of our values especially for those using same method of extraction were previously shown by El- 
Nemr et al. (1990) in which the edible parts of pomegranate fruit represented $52 \%$ of total fruit weight as arils, comprising $78 \%$ juice and $22 \%$ seeds. Similarly

Table (1): Weight fruits components, and revenue percent of pomegranate juices extracted by squeezing and centrifugation methods.

\begin{tabular}{|l|c|c|c|c|c|c|}
\hline Pomegranate Juice and & Weight of & Arils & Juice & \multicolumn{3}{|c|}{ \% Revenue } \\
\cline { 5 - 8 } & Fruits, g & $\mathrm{g}$ & $\mathrm{g}$ & $\begin{array}{c}\text { Arils of } \\
\text { whole fruits }\end{array}$ & $\begin{array}{c}\text { Juice of } \\
\text { Arils }\end{array}$ & $\begin{array}{c}\text { Juice of } \\
\text { Whole fruits }\end{array}$ \\
\hline Sour/squeezing & $1014 \mathrm{ab}$ & & $375 \mathrm{c}$ & & & $37 \mathrm{c}$ \\
\hline Sour/centrifugation & $1013 \mathrm{abc}$ & $673 \mathrm{~b}$ & $525 \mathrm{~b}$ & $66.4 \mathrm{~b}$ & $78 \mathrm{~b}$ & $51.8 \mathrm{~b}$ \\
\hline Sour-sweet/ squeezing & $1008 \mathrm{bc}$ & & $525 \mathrm{~b}$ & & & $52 \mathrm{~b}$ \\
\hline Sour-sweet/ centrifugation & $1021 \mathrm{a}$ & $761 \mathrm{a}$ & $555 \mathrm{a}$ & $74.5 \mathrm{a}$ & $74 \mathrm{c}$ & $54 \mathrm{a}$ \\
\hline sweet/ squeezing & $1009 \mathrm{bc}$ & & $375 \mathrm{c}$ & & & $37 \mathrm{c}$ \\
\hline sweet/ centrifugation & $1004 \mathrm{c}$ & $671 \mathrm{~b}$ & $550 \mathrm{a}$ & $66.8 \mathrm{~b}$ & $82 \mathrm{a}$ & $54.8 \mathrm{a}$ \\
\hline
\end{tabular}

Values represent three experimental samples.

Different letters in the same column means there are significant $(\mathrm{P}<0.05)$ differences.

Aviram et al. (2000) stated that edible parts of pomegranate fruit (about $50 \%$ of total fruit weight) comprise $80 \%$ juice and $20 \%$ seeds. Other present values especially that of using squeezing method were higher than those of literature.

Table (2) shows chemical composition of pomegranate juices extracted by squeezing and centrifugation methods. Results show that moisture content of these juices ranged between 83.1 to $86.2 \%$ compared with $81.3 \%$ for local commercial juice. Results also show that there were little differences in moisture among the pomegranate juices in which the lowest moisture was $83.1 \%$ in sweet pomegranate juice extracted by centrifugation compared with highest value of $86.2 \%$ in sour pomegranate juice extracted by squeezing. These values were higher than moisture in local commercial pomegranate juice $(81.3 \%)$ and this may be due to the higher Total Soluble solid percent of $17.2 \%$ in this juice. From the Table results show that TSS ranged between 11.2 to $15.8 \%$ and this range might be due to the differences in maturity and other factors related to soil and environment conditions and may be due to the extraction methods. However, percent of TSS was significantly $(\mathrm{P}<0.05)$ higher in the juices using squeezing method $(12.8,14.0$ and $15.8 \%)$ from respective sour, sour-sweet and sweet pomegranate fruits compared with lower values $(11.2,11.2$ and 14.9) by using centrifugation method of extraction from respective sour, sour-sweet and sweet pomegranate fruits. The value TSS in local commercial pomegranate juice was higher $(17.2 \%)$ and this might be due to concentrate the juice in order to increase the stability against chemical reactions and microbial activity by decreasing water activity $\left(a_{W}\right)$ and also to decrease the volume of the juice to facilitate handling and marketing (Crandall and Graumlich, 1982). Nevertheless, our results of pomegranate moisture were closed enough to those of El-Nemr et al. (1990) in which they found that fresh pomegranate 
juice contained $85.4 \%$ moisture. Similar result (85.95\% moisture) was recently tabulated by USDA (2011). However, Akbarpour et al. (2009) found that total soluble solid ranged from 15.17 to 22.03 ( ${ }^{\circ}$ Brix) in twelve pomegranate cultivars juices.

Table (2): Chemical composition of Pomegranate Juice extracted by squeezing and centrifugation methods $(\mathrm{g} / 100 \mathrm{~g})$.

\begin{tabular}{|l|c|c|c|c|c|c|c|c|}
\hline $\begin{array}{l}\text { Pomegranate Juice } \\
\text { and Extraction } \\
\text { methods }\end{array}$ & Moisture & TSS & Protein & $\begin{array}{c}\text { Lipid } \\
\text { extract }\end{array}$ & $\begin{array}{l}\text { Crude } \\
\text { Fiber }\end{array}$ & Ash & Carbohydrate* & $\begin{array}{c}\text { Energy } \\
\text { Kcal/100g }\end{array}$ \\
\hline Sour/squeezing & $86.2 \mathrm{a}$ & $12.8 \mathrm{e}$ & $0.6 \mathrm{c}$ & $0.60 \mathrm{~cd}$ & $0.1 \mathrm{e}$ & $0.48 \mathrm{ab}$ & $12.02 \mathrm{~d}$ & 55.88 \\
\hline Sour/centrifugation & $84.8 \mathrm{ab}$ & $11.2 \mathrm{f}$ & $0.7 \mathrm{~b}$ & $0.56 \mathrm{~cd}$ & $0.2 \mathrm{~d}$ & $0.56 \mathrm{a}$ & $13.18 \mathrm{c}$ & 60.56 \\
\hline $\begin{array}{l}\text { Sour-sweet/ } \\
\text { squeezing }\end{array}$ & $84.0 \mathrm{bc}$ & $14.0 \mathrm{~d}$ & $0.7 \mathrm{~b}$ & $0.55 \mathrm{~d}$ & $0.3 \mathrm{c}$ & $0.40 \mathrm{~b}$ & $14.05 \mathrm{~b}$ & 63.95 \\
\hline $\begin{array}{l}\text { Sour-sweet/ } \\
\text { centrifugation }\end{array}$ & $83.8 \mathrm{bc}$ & $11.2 \mathrm{f}$ & $0.8 \mathrm{~d}$ & $0.63 \mathrm{c}$ & $0.4 \mathrm{~b}$ & $0.48 \mathrm{ab}$ & $13.89 \mathrm{~b}$ & 64.43 \\
\hline Sweet/ squeezing & $83.2 \mathrm{bc}$ & $15.8 \mathrm{~b}$ & $0.7 \mathrm{~b}$ & $0.61 \mathrm{c}$ & $0.5 \mathrm{~b}$ & $0.52 \mathrm{a}$ & $14.47 \mathrm{~b}$ & 66.17 \\
\hline $\begin{array}{l}\text { Sweet/ } \\
\text { centrifugation }\end{array}$ & $83.1 \mathrm{c}$ & $14.9 \mathrm{c}$ & $0.8 \mathrm{a}$ & $0.72 \mathrm{~b}$ & $0.6 \mathrm{a}$ & $0.56 \mathrm{a}$ & $14.22 \mathrm{~b}$ & 66.48 \\
\hline Local Juice & $81.3 \mathrm{~d}$ & $17.2 \mathrm{a}$ & $0.8 \mathrm{a}$ & $0.85 \mathrm{a}$ & $0.6 \mathrm{a}$ & $0.52 \mathrm{a}$ & $15.93 \mathrm{a}$ & 74.57 \\
\hline
\end{tabular}

*Calculated by difference

The values are average of three samples.

Different letters in the same column means there are significant $(\mathrm{P}<0.05)$ differences.

Results show that the TSS and carbohydrates percent in sour pomegranate juice of extracted by squeezing were low (12.8 and $12.12 \%$, respectively) compared with little high values of other juices. This may be due to the higher moisture content $(86.2 \%)$ in sour pomegranate juice extracted by squeezing method on the expense of other components. Other TSS and carbohydrates percent ranged between the lower values of 11.2 and $13.38 \%$, respectively for sour pomegranate juice extracted by centrifugation method and the highest values of 15.8 and $15.93 \%$, respectively for sweet pomegranate juice extracted by squeezing method and sour sweet pomegranate extracted by centrifugation method compared with 17.2 and $17.25 \%$, respectively for local commercial pomegranate juice. However, carbohydrates values are calculated by difference between the whole constituents and the sum of other rest constituents. So, their values might be increases or decreases depending on increasing or decreasing the values of proteins, fat, fibers and ash percent in the juices. Data in the Table show that pomegranate juices were not opulent sources of protein and lipid extract compared with the seeds of arils which contain high percent of protein, lipid fibers and sugars (ElNemr et al.,1990) in which protein content ranged 0.6 to $0.8 \%$ compared with $0.8 \%$ for local commercial pomegranate juice. The fat extract ranged 0.55 to $0.72 \%$ compared with $0.85 \%$ for local commercial pomegranate juice. There were no specific differences of protein or ether extract among pomegranate species or treatments. Crude fiber content of pomegranate juices was ranged between 0.1 and $0.6 \%$ compared with local juice of $0.6 \%$. However, present results for protein, crude fat and fiber were higher than those Tabulated by Anonymous (2011). Ash content ranged 0.40 to $0.56 \%$ compared with $0.52 \%$ for local commercial pomegranate juice in which contained ash within the range of other juices. The values were higher than those $(0.05 \mathrm{~g} / 100 \mathrm{ml})$ in 
fresh pomegranate juice observed by El-Nemr et al. (1990), however these results were comparable with the value $(0.49 \%)$ of Anonymous (2011). Calculated total energy ranged 55.88 to $66.48 \mathrm{Kcal} / 100 \mathrm{~g}$ juice compared with $74.57 \mathrm{Kcal} / 100 \mathrm{~g}$ juice for local commercial pomegranate juice. These values were almost in agreement to the value (54 kcal/100 g) published by Anonymous (2011).

Table (3) shows some characteristic and constituents of pomegranate juices extracted by squeezing and centrifugation methods. Total sugar values for all juices were correspondingly in the same manner in which the lowest value was $11.81 \%$ for sour pomegranate juice extracted by squeezing method and the highest value of 14.39 $\%$ for sour sweet pomegranate juice extracted by centrifugation also compared with $16.57 \%$ total sugars in local commercial pomegranate. The lowest values of total sugars in sour pomegranate juice extracted by squeezing and centrifugation methods were companying with higher acidity (3 and $2.04 \%$, respectively) compared with other juices. Nevertheless, the higher total sugars and acidity in local pomegranate juice were due to increasing in concentration of the juice. Eksi and Ozhamamc (2009) found that the range of total sugars in pomegranate juices of 23 samples was 9.6 - $13.7 \mathrm{~g} / 100$ (96$137 \mathrm{~g} / \mathrm{L})$. Our values for total sugars are almost in agreement with these value and other values (12.65\%) tabulated by Anonymous (2011), but little higher than the value (10.6\%) found by El-Nemr et al. (1990). The percentage of total soluble sugars was differed according to stage of maturity in which increases in sweet and sour sweet pomegranate juices with increasing period of maturity more than sour pomegranate resulting in increasing of quantity compared with other constituents of the TSS in the juices (Hulme, 1971). It has been known that most of the total soluble sugars are reducing sugars which represent mostly as glucose and fructose with traces of sucrose and may be other sugars and glucose and fructose were almost occurred in equal amounts (Cemeroglu et al., 1992; Miguel et al., 2004 and Eksi and Ozhamamc, 2009). The range of reducing sugars ranged between the lowest values of $11.4 \%$ in the sour pomegranate extracted by squeezing method to highest value of $14.0 \%$ in sour sweet pomegranate juice extracted by centrifugation method compared with little higher value $(16.17 \%)$ for local commercial juice. Results show that there were no differences in reducing sugars between the two extraction methods.

Results from Table (3) show that the lowest values of glucose and fructose were 5.2 and $5.8 \%$, respectively in sour pomegranate juice extracted by squeezing method and the highest values were 6.7 and $6.9 \%$, respectively in sweet juice extracted by centrifugation method and in sour sweet juice extracted by centrifugation method, respectively compared with 8.2 and $7.8 \%$, respectively in local commercial. These results were among the range of glucose and fructose values in 23 samples of pomegranate juices found by Eksi and Ozhamamc (2009). Results show that there were no clear significantly $(\mathrm{P}<0.05)$ differences in glucose and fructose between the two extraction methods. Non reducing sugars are not abundant in pomegranate juices compared with reducing sugars (Table 3 ). The non reducing sugars for all pomegranate juice samples ranged between $0.38-0.41 \%$ compared with $0.4 \%$ for local juice. These values were higher than value $(0.1 \mathrm{~g} / 100 \mathrm{ml})$ obtained by El-Nemr et al. (1990).

Ascorbic acid values in Table (3) ranged between $5.95 \mathrm{mg} / 100 \mathrm{ml}$ in sweet 
Mesopotamia J. of Agric. Vol. (42) No. (1) 2014
ISSN: 2224-9796 (Online)

ISSN: $1815-316$ X (Print)
مجـلـة زر اعـــة الر افديــن المجلد (42) العدد(1) 2014

Table (3): Some characteristic of Pomegranate Juices extracted by squeezing and centrifugation methods (g/100g).

\begin{tabular}{|l|c|c|c|c|c|c|c|c|}
\hline $\begin{array}{l}\text { Pomegranate Juice and } \\
\text { Extraction methods }\end{array}$ & $\begin{array}{c}\text { Total } \\
\text { sugar }\end{array}$ & $\begin{array}{c}\text { Reducing } \\
\text { sugar }\end{array}$ & Glucose & Fructose & $\begin{array}{c}\text { Non } \\
\text { reducing } \\
\text { sugar }\end{array}$ & $\begin{array}{c}\text { Vit C } \\
\mathrm{mg}\end{array}$ & $\begin{array}{c}\text { Titrable } \\
\text { Acidity }\end{array}$ \\
\hline Sour/squeezing & $11.81 \mathrm{~g}$ & $11.4 \mathrm{f}$ & $5.2 \mathrm{f}$ & $5.8 \mathrm{~g}$ & $0.41 \mathrm{a}$ & $7.1 \mathrm{a}$ & $2.59 \mathrm{c}$ & $3.00 \mathrm{~b}$ \\
\hline Sour/centrifugation & $12.64 \mathrm{f}$ & $12.6 \mathrm{e}$ & $5.9 \mathrm{e}$ & $6.1 \mathrm{f}$ & $0.4 \mathrm{a}$ & $6.6 \mathrm{ab}$ & $2.69 \mathrm{c}$ & $2.04 \mathrm{c}$ \\
\hline Sour-sweet/ squeezing & $13.70 \mathrm{e}$ & $13.3 \mathrm{~d}$ & $6.62 \mathrm{bc}$ & $6.63 \mathrm{c}$ & $0.4 \mathrm{a}$ & $6.3 \mathrm{bc}$ & $3.24 \mathrm{~b}$ & $1.20 \mathrm{~d}$ \\
\hline Sour-sweet/ centrifugation & $14.39 \mathrm{~b}$ & $14.0 \mathrm{~b}$ & $6.4 \mathrm{~d}$ & $6.9 \mathrm{~b}$ & $0.39 \mathrm{a}$ & $6.1 \mathrm{bc}$ & $3.50 \mathrm{ab}$ & $0.96 \mathrm{e}$ \\
\hline sweet/squeezing & $14.20 \mathrm{c}$ & $13.79 \mathrm{c}$ & $6.6 \mathrm{~b}$ & $6.4 \mathrm{~d}$ & $0.41 \mathrm{a}$ & $6.1 \mathrm{bc}$ & $3.53 \mathrm{ab}$ & $0.76 \mathrm{f}$ \\
& & & & & & & & \\
\hline sweet/ centrifugation & $14.10 \mathrm{~d}$ & $13.72 \mathrm{c}$ & $6.7 \mathrm{c}$ & $6.3 \mathrm{e}$ & $0.38 \mathrm{a}$ & $5.95 \mathrm{c}$ & $3.71 \mathrm{a}$ & $0.51 \mathrm{~g}$ \\
\hline Local Juice & $16.57 \mathrm{a}$ & $16.17 \mathrm{a}$ & $8.2 \mathrm{a}$ & $7.8 \mathrm{a}$ & $0.4 \mathrm{a}$ & $6.1 \mathrm{bc}$ & $2.28 \mathrm{c}$ & $3.52 \mathrm{a}$ \\
& & & & & & \\
\hline
\end{tabular}

The numbers are average of three samples

Different letters in the same column means there are significant $(\mathrm{P}<0.05)$ differences. 
Mesopotamia J. of Agric.

Vol. (42) No. (1) 2014
ISSN: 2224-9796 (Online)

ISSN: $1815-316 \mathrm{X}$ (Print)

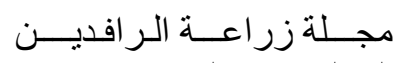
المجلد (42) العدد(1) 2014 العران

pomegranate juice extracted by centrifugation and $7.0 \mathrm{mg} / 100 \mathrm{ml}$ in sour pomegranate juice extracted by squeezing method compared with $6.1 \mathrm{mg} / 100 \mathrm{ml}$ in local commercial

pomegranate juice. These results of ascorbic acid are within the range values (0.0-12.0 \pm 2.6 $\mathrm{mg} / 100 \mathrm{ml})$ but little higher than the average content $(3.43 \mathrm{mg} / 100 \mathrm{ml})$ for 17 cultivars of pomegranate found by Aarabi et al. (2008). These values were high compared with literature values of El-Nemr et al. (1990) $(0.7 \mathrm{mg} / 100 \mathrm{ml})$ and USDA (2011) $(0.1 \mathrm{~m} / 100$ $\mathrm{ml}$ ). However, Akbarpour et al. (2009) found that vitamin C content ranged between 9.68$17.45 \mathrm{mg} / 100 \mathrm{ml}$ in twelve pomegranate cultivars juices.

$\mathrm{pH}$ values of pomegranate juice also differ according to the variety, degree of maturity and the soil and environment conditions. Results from Table (3) show that $\mathrm{pH}$ values ranged between the lowest (2.59) for sour pomegranate juice extracted by squeezing method and the highest (3.71) value of sweet pomegranate juice extracted by centrifugation method compared with 2.28 for local commercial pomegranate juice. Similarly, Akbarpour et al. (2009) found that $\mathrm{pH}$ values of twelve pomegranate cultivars juices ranged between 2.75 to 4.14 . Results show that the $\mathrm{pH}$ values for sour pomegranate juices were lower than those of sweet pomegranate juices; however, the values were slightly increased in all juices extracted by centrifugation compared with

squeezing methods. Same methods followed by Miguel et al. (2004) for pomegranate juice extraction did not affect $\mathrm{pH}$ values. Organic acids are considered as the most important constituents of total solid of the juices (Kale and Adsule, 1995). The determination of total acidity is considered as one of the most indices for definition of ripeness, acceptability to the processing and determination of fruits quality (Fellers, 1991). Further, the taste of juices was affect by organic acids instead of $\mathrm{pH}$ value

(Dalaly and Al-Hakim, 1987). Further, Wang et al. (1993) and Blanco et al. (1996) stated that organic acids are considered as good index to estimate the quality of fruits

and their products. Previously, Hulme (1971) mentioned that the acidity of the organic acids is related to the number and the site of the carboxyl groups in organic acid molecule. Table (3) also shows the titrable acidity of pomegranate juices considered as percent citric acid. Results show that the lowest titrable acidity was $0.51 \%$ for sweet pomegranate juice extracted by centrifugation method and the highest (3.0\%) values for sour pomegranate juice extracted by squeezing method compared with $3.52 \%$ for local commercial pomegranate juice. Results show that the titrable acidity for sour pomegranate juices were significantly $(\mathrm{P}<0.05)$ higher than those of sweet, however, the values were significantly $(\mathrm{P}<0.05)$ decreased in all juices extracted by centrifugation compared with squeezing methods. Same methods followed by Miguel et al. (2004) for pomegranate juice extraction did not affect organic acids composition. The titrable acidity values of this study were little higher for sour pomegranate juices than those values $(0.83-1.74 \%)$ found by Eksi and Ozhamamc (2009) in 23 samples of pomegranate juices, and in some cases similar to other juice samples.

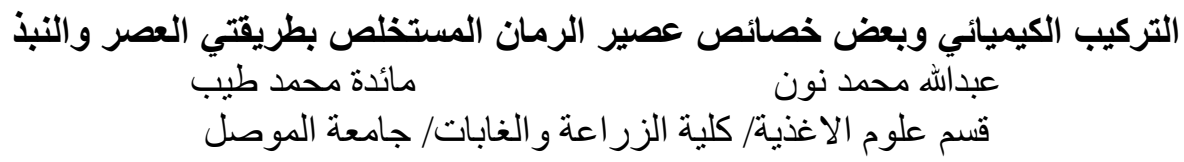

E-mail: dr_thannoun@yahoo.Com 
Mesopotamia J. of Agric.

Vol. (42) No. (1) 2014
ISSN: 2224-9796 (Online)

ISSN: $1815-316 \mathrm{X}$ (Print)

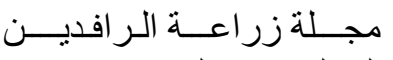

المجلد (42) العدد(1) 2014 الحرن

\section{الخلاصة}

تم استخلاص عصير ثلاثة من اصناف الرمان (Punica granatum L) المحلية المصنفة على اسلس الطعم وهي

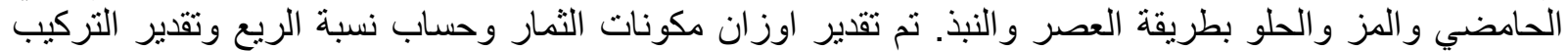

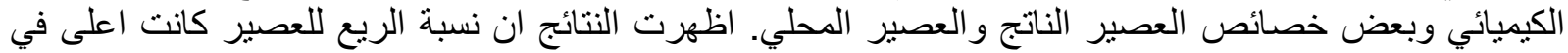

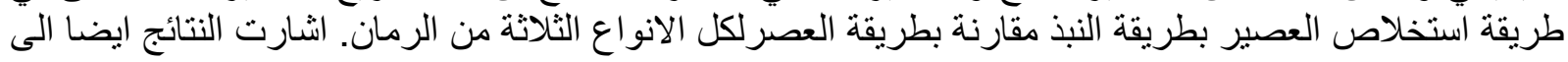

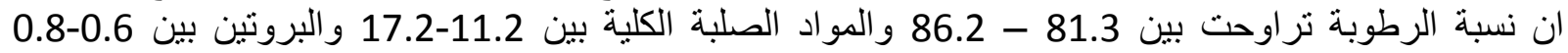

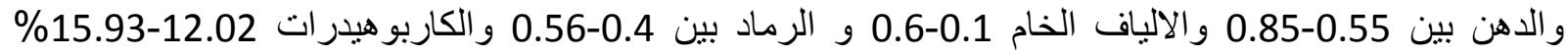

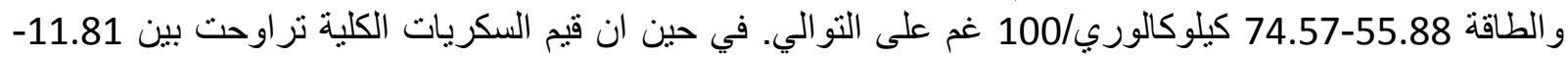

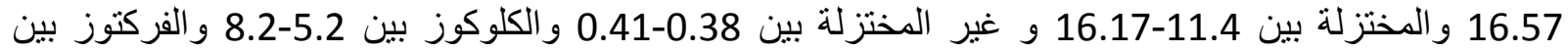

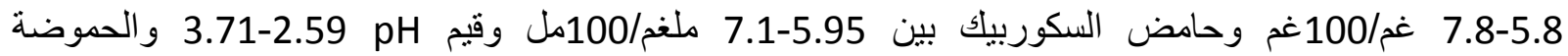

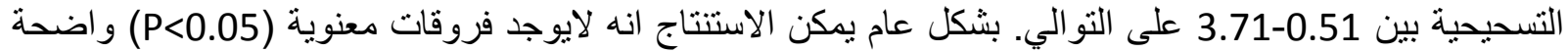

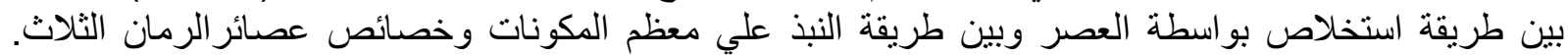
كلمات دالة: حامض اسكوربيك، التركيب الكيميائي، الاستخلاص، عصير الرمان، سكريات.

تاريخ تسلم البحث 22 / 4 / 2012 وقبوله 18 / 62012

\section{REFERENCES}

Aarabi, A.; M. Barzegar and M. H. Azizi (2008). Effect of cultivar and cold storage of pomegranate (Punica granatum L.) juices on organic acid composition. Asean Food Journal 15 (1): 45-55.

Akbarpour, V. K. Hemmati and M. Sharifani (2009). Physical and chemical properties of pomegranate (Punica granatum L.) fruit in maturation stage. American-Eurasian Journal of Agriculture and Environment Science, 6 (4): 411-416.

Anonymous (2000). Official Methods of Analysis, $13^{\text {th }}$ Ed. Association of Official Analytical Chemists (AOAC)., Washington, DC.

Anonymous (2011). United State Department of Agriculture (USDA). National Nutrient Database for Standard Reference Release 24 (2011). Pomegranate juice, bottled. NDB No: 09442

Aviram, M., L. Dornfeld, M. Rosenblat, N. Volkova, M. Kaplan, R. Coleman, T. Hayek, D. Presser and B. Fuhrman (2000). Pomegranate juice consumption reduces oxidative stress, atherogenic modifications to LDL, and platelet aggregation: studies in humans and in atherosclerotic apolipoprotein E-deficient mice. American Journal of Clinical Nutrition 71(5): 1062-1076.

Blanco, D.; J. Quintanilla and J. Gutierrez (1996). Determination of organic acids in apple juices by capillary liquid chromatography. Journal of Liquid Chromatography. Rel. Technology 19:2615-2621.

Cemeroglu, B.; N. Artik and S. Erbas (1992). Extraction and composition of pomegranate juice. Fluessiges obstract 59 (6):335-40.

Clifford, M. N. and A. Scalbert (2000). Ellagitannins-nature, occurrence and dietary burden. Journal of Science and Food Agriculture 80:1118-25.

Crandall, P. and T. Graumlich (1982). Storage stability and quality of high brix orange concentrate. Proceedings of the Florida State Horticultural Society. 95:198-202.

Dalaly, B. K and S. H. Al-Hakim (1987) Food Analysis. Dar Alkutob For Printing and Publication, University of Mosul.

Ekşi, A. İ. Özhamamc (2009). Chemical composition and guide values of pomegranate juice. GIDA 34 (5): 265-270. 
Mesopotamia J. of Agric.

Vol. (42) No. (1) 2014
ISSN: 2224-9796 (Online)

ISSN: $1815-316 \mathrm{X}$ (Print)

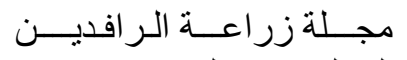

المجلد (42) العدد(1) 2014 العند

EL-Nemr, S. E.; I. A. Ismail and M. Ragab (1990). Chemical composition of juice and seeds of pomegranate fruit. Die Nahrung 34 (7): 60-606.

Fellers, P. (1991). The relation between the ratio of degrees brix to percent acid and sensory flavor in grapefruit juice. Food Technology 45:68-75.

Gil, M. I; F. A. Tomas-Barberan; B. Hess-Pierce; D.M Holcroft and A.A. Kader (2000). Antioxidant activity of pomegranate juice and its relationship with phenolic composition and processing. Journal of Agriculture and Food Chemistry 48 (10):4581-4589.

Hulme, A. C. (1971). The Biochemistry of Fruits and Their Products. Vol. 2. Academic Press, London and New York.

Jurenka, J. (2008). Therapeutic applications of pomegranate (Punica granatum L.):

A Review. Alternative Medical Review 13(2):128-144.

Kale, P. and P. Adsule (1995). Citrus production, composition, storage and processing. In: "Handbook of Fruit Science and Technology". Edited by D. K. Salunkhe and S. Kadan . Marcel Dekker, New York.p.39-65.

Lansky E.P. and R. A. Newman (2007). Punica granatum (pomegranate) and its potential for prevention and treatment of inflammation and cancer. Journal of ethnopharmacology 109 (2):177-206.

Ling, E. R. (1963). A Text Book of Dairy Chemistry. 3rd Ed, Chapman and Hall Ltd., London.

Melgarejo P and D. M. Salazar, F. Artés (2000). Organic acids and sugars composition of harvested pomegranate fruits. European Food Research Technology 2: 211(3):185190.

Miguel G.; S. Dandlen; D. Antunes; A. Neves and D. Martins (2004). The effect of two methods of pomegranate (Punica granatum $\mathrm{L}$ ) juice extraction on quality during storage at $4^{\circ} \mathrm{C}$. Journal of Biomedical Biotechnology 5 (1): 332-337.

Ranganna S. (1977). Manual of Analysis of Fruit and Vegetable Products, Tata MacGraw Hill Company Ltd, New Delhi.

Seeram, N. P., S. M. Henning, Y. Zhang, M. Suchard, Z. Li and D. Heber (2006). Pomegranate juice ellagitannin metabolites are present in human plasma and some persist in urine for up to 48 hours. Journal of Nutrition 136 (10): 2481-2485.

Steel, R. G. D. andJ. H. Torrei (1980). Analysis of Principales and Pocedures of Statistics. $2^{\text {nd }}$ Ed McGraw Hill, N. Y, USA.

Viuda-Martos, M.; J. Fern'andez-L'opez and J.A. P'erez-'Alvarez (2010). Pomegranate and its many functional components as related to human health: A Review. Comprehensive Reviews in Food Science and Food Safety 9: 635-654.

Wang, T.; A. Gonzalez and J. Aselage (1993). Organic acid changes during ripening of processing peaches. Journal of Food Science 58: 631-632. 